University of Wollongong

Research Online

Faculty of Arts, Social Sciences and Humanities

- Papers

Faculty of Arts, Social Sciences \& Humanities

$1-1-2020$

\title{
Urban governance dispositifs: cohering diverse ecologies of urban energy governance
}

\author{
Pauline M. McGuirk \\ University of Wollongong, pmcguirk@uow.edu.au \\ Robyn Dowling
}

Follow this and additional works at: https://ro.uow.edu.au/asshpapers

Research Online is the open access institutional repository for the University of Wollongong. For further information contact the UOW Library: research-pubs@uow.edu.au 


\title{
Urban governance dispositifs: cohering diverse ecologies of urban energy governance
}

\author{
Abstract \\ (c) The Author(s) 2020. As cities confront increasingly complex governance problems, conceptions of \\ urban governance are becoming progressively more receptive to grasping its dynamic and multiplex \\ nature, its connection to multiple lines of authority and forms of power, and the socio-material \\ assemblages through which it works. Yet, despite conceptual advances around the dynamism and \\ heterogeneity of urban governing assemblages and their durability, much remains to be understood about \\ the processes and devices that compose and cohere their constituent elements to generate governance \\ capacity. We explore this limitation by deploying Foucault's concept of 'dispositif' to analytically \\ characterize how urban governance capacity is achieved around complex urban problems via processes \\ and devices of composition and cohering. We do so by examining an emergent urban energy governance \\ dispositif focused around top-tier commercial office space in Sydney, Australia: a key site around which \\ multiple elements have been composed in a complex, entangled dispositif to produce effective urban \\ governance capacity and accomplish substantive gains in office building energy performance. We \\ characterise the socio-material elements involved and, more particularly, identify and analyse the \\ processes and devices that compose the dispositif and cohere its governance capacity and we draw out \\ the diverse forms of power that are immanent in these processes. These are, we argue, key steps in \\ refining systematic understandings of the contemporary functioning and politics of the distributed urban \\ governance of complex urban challenges. We conclude with key observations suggested by our analysis \\ for urban governance scholarship.

\section{Publication Details} \\ McGuirk, P. \& Dowling, R. (2020). Urban governance dispositifs: cohering diverse ecologies of urban \\ energy governance. Environment and Planning C: Politics and Space,
}


Urban governance dispositifs: cohering diverse ecologies of urban energy governance

\title{
MGouirk PM
}

School of Geography and Sustainable Communities, University of Wollongong

\author{
Dowling R \\ Faculty of Architecture, Planning and Design, University of Sydney
}

Paper published in Environment and Planning A 2020

DOI 10.1177/2399654420957329

\section{Funding}

\section{ARCDP 150100991}

\begin{abstract}
As cities confront increasingly complex governance problems, conceptions of urban governance are becoming progressively more receptive to grasping its dynamic and multiplex nature, its connection to multiple lines of authority and forms of power, and the socio-material assemblages through which it works. Yet, despite conceptual advances around the dynamism and heterogeneity of urban governing assemblages and their durability, much remains to be understood about the processes and devices that compose and cohere their constituent elements to generate governance capacity. We explore this limitation by deploying Foucault's concept of 'dispositif' to analytically characterize how urban governance capacity is achieved around complex urban problems via processes and devices of composition and cohering. We do so by examining an emergent urban energy governance dispositif focused around top-tier commercial office space in Sydney, Australia: a key site around which multiple elements have been composed in a complex, entangled dispositif to produce effective urban governance capacity and accomplish substantive gains in office building energy performance. We characterise the socio-material elements involved and, more particularly, identify and analyse the processes and devices that compose the dispositif and cohere its governance capacity and we draw out the diverse forms of power that are immanent in these processes. These are, we argue, key steps in refining systematic understandings of the contemporary functioning and politics of the distributed urban governance of complex urban challenges. We conclude with key observations suggested by our analysis for urban governance scholarship.
\end{abstract}

KEY WORDS: Urban governance; Dispositif;Governance capacity; Composition and Cohering; Energy governance 


\section{Introduction}

Urban governance in western cities is widely understood to be a dynamic phenomenon comprised of a diverse socio-materiality and connected to multiple lines of authority. Over the last 30 years, approaches such as urban regime theory and networked governance have understood urban governance as a collective achievement; assuming the co-presence of public/private/community actors in delivering outcomes and posing the challenge of "how, in a world of limited and dispersed authority, do actors work together across institutional lines to produce a capacity to govern and to bring about publicly significant results?" (Stone 1989:8-9). Although much has been gained from this work, a notion of the central steering agency of 'the state' in orchestrating governance remains, along with tendencies to commence analysis with the state and to assume the governance capacity of state-led interventions with vestiges of 'command and control' (eg Hajer et al 2015). Limitations concerning these tendencies have become increasingly clear in light of contemporary uncertainties associated with the urban anthropocene, smart technologies, COVID-19 and the turn towards cities and urban capacities to govern such global scale challenges (Derickson 2018).

Engaging with these limitations, recent urban scholarship has sought to capture the new political spaces and practices emerging in the contemporary city and, relatedly, to expand how we conceptualise urban governance and the modes through which is it achieved. Analyses have engaged notably with urban experimentation (Evans et al 2016), coproduction (Chatterton et al 2018) and socio-technologies (Bissell 2018). These developments have been most pronounced in contextual analyses that unpack the urban governance of the smart city (Karvonen et al 2019), climate change (Bulkeley 2015), resilience (Braun 2014) and, pertinent to this paper, energy (Haarstad 2016). Scholars have also drawn on assemblage and STS-inflected thinking to understand the fluid, dynamic and multiplex nature of urban governance and the socio-materialities through which it works (MGuirk et al 2016a, Rydin 2013). Collectively, this work refines the conception of urban governance not merely as polycentric but as a set of diverse, loosely connected efforts enacted through both material and social means and not necessarily connected to a singular overarching plan, central logic or centralised steering capacity (Bissell 2018, Braun 2014). 
One key idea becoming increasingly productive in this reframing of urban governance is Foucault's concept of 'dispositif' or apparatus. Dispositif suggests "an emergent set of loose things and practices joined by governing nodes in a system of correlation" (Bracking 2019:714). This 'system of correlation' somehow draws together heterogenous elements, even precariously and temporarily, to produce effective governance capacity in any given domain. Dispositif's focus on diffuseness, heterogeneity, provisionality and, crucial to this paper's concerns, systems of correlation, presents a key opportunity for the analysis of the contemporary complexity of governing the urban. Conceptual work on the dynamism and heterogeneity entailed in governing that is suggested in the dispositif approach is relatively well developed, informed particularly by assemblage theory, and work is advancing on how governing assemblages are made durable. Despite these advances, investigation of the processes and devices that cohere the elements that constitute dispositifs are rarer (Tozer 2019, Stripple and Bulkeley 2019). As a result, this key stage in the workings of 'systems of correlation' is less well understood, conceptually and empirically. In light of the composition of new urban dispositifs to govern complex, emergent urban problems, greater attention needs to be paid to the processes through which heterogeneous, widely scattered and dynamically emergent elements are drawn together and cohered to produce the capacity to govern.

This paper uses the concept of dispositif and detailed empirically-informed induction to analytically characterise how urban governance capacity is achieved around a complex urban problem. We do so by examining the composition of an energy governance dispositif focused around office buildings in Sydney, Australia. We identify the socio-material elements and characterise the processes and devices that operate across sectors and scales to compose and cohere the dispositif, so producing governance capacity. Sydney's urban office energy governance is useful in addressing the question to hand because it presents a microcosm of the complexity and heterogeneity of contemporary urban governance writ large. In Sydney, in the absence of strong political leadership, and in a complex institutional, regulatory and economic context, governance capacity to reduce energy consumption in the sector has been successfully realised. Our analysis loosens analytical ties to "static and scale-based assumptions of how governance is achieved" (Bulkeley and Betsill 2013:150), extends attention to the "messy, materially-embedded" means through which governing 
capacity is produced (Tozer 2019:108) and so contributes to refining understandings of contemporary urban governance. It offers new insights into the systems of correlation that compose and cohere the multiple dispositifs that make governance possible in complex urban contexts, and provokes analytical questions about the emergent politics and forms of power that drive such governance.

\section{Urban governance as dispositif}

Dispositif-or apparatus of government-is defined by Foucault as "a thoroughly heterogeneous ensemble consisting of discourses, institutions, architectural forms, regulatory decisions, laws, administrative measures, scientific statements, philosophical, moral and philanthropic propositions" (cited in Ploger 2008). Dispositif suggests "an emergent set of loose things and practices joined by governing nodes in a system of correlation" (Bracking 2019:714). The multiplexity of a dispositif led Delueze (1992:159) to conceptualise them as "a tangle, a multilinear ensemble". The concept entails an embrace of emergence, complexity and fluidity, in conjunction with a settlement of arrangements through which governing authority over subjects occurs. For Agamben (2009: 14) this authority is realised in a dispositif's ability to "capture, orient, determine, intercept, model, control or secure" human thought and behaviour. Crucially, dispositifs are taken to form as diverse practices are stitched together in response to a specific 'urgency' or problematic. As such, they are essentially strategic in nature (Rabinow and Rose 2003) and thus "always inscribed in power" (Agamben 2009:2). The management of the urban is crowded with such dispositifs.

Two broad and sympathetic strands of work on urban governance, though not explicitly deploying the concept of dispositif, work in a sympathetic register: assemblage-informed work captures the heterogenous, multi-sited actors and elements involved in actualising governance across urban domains such as regeneration ( $M \subseteq$ Guirk et al 2016b), economic development (Allen and Cochrane 2007) and social policy (McCann 2011), while STSinflected work captures the techno-material nature of urban governance across domains such as urban energy (Rutherford 2014, MGuirk et al 2019), and smart infrastructure and big data (Kitchin et al 2017)i. These strands are implicit in the analysis that follows. Indeed, there are certain challenges in distinguishing assemblage from dispositif, not least because 
the terms are sometimes merged in their use both by Foucault and Deleuze. Furthermore, the concepts of assemblage and dispositif share multiple resonances. ${ }^{i i}$ In terms of the key concerns of our analysis, dispositif thinking-like assemblage thinking-positions governance as involving state and extra-state elements, operating across multiple technologies, spatialities and temporalities, across which multiple political projects and logics are in play (Tozer 2019). Equally both assemblage and dispositif assume that governing agency is not exclusively social but material and technological. Human actors, technical devices and material practices are bound up with each other in how the dispositif is composed and cohered ( $\mathrm{M} \subseteq$ Guirk et al 2016a). Yet assemblage analyses of the urban have tended to concentrate on tracing connections between diverse, often translocal, elements that constitute urban socio-spatial formations. Work on policy mobility for instance has productively traced the constitution of urban policy formations and the arrangement of its elements, as well as analysing the purposeful actions and socio-material labours entailed in holding policy assemblages together (eg McCann and Ward 2011, Prince 2014). Dispositifthinking, by comparison, brings additional analytical capabilities that are especially productive for developing understandings of the changing forms of urban governance. Three stand out.

First, dispositif sharpens our analytical focus via its exclusive attention to questions of government. Legg (2011: 131), for examples, sees dispositif as "indissociable from regulation and government", tightly focussed on questions of ordering, consolidating and governing, and can be thought of as "an actually existing heterogenous multiplicity that governs" (p.132). Second, while some assemblage thinkers explicitly address questions of strategy and power (e.g. McFarlane 2009), this focus is not an analytical necessity in assemblage analyses. Comparatively, dispositif thinking is specifically attuned to how the play of power operates as a dispositif takes shape (Legg 2011) given that a dispositif "always has a concrete strategic function and is always located in a power relation" (Agamben 2009: 3). As such, dispositif thinking is especially receptive to how multiple modes of governing operate through diverse modalities of power (Kitchin et al 2017). In our analysis we leverage the dispositif approach's embrace of the embeddedness of governance in power plays and its affinities with a relational view of power as a productive capacity produced in situated networks of socio-material interactions (Cupples 2011:940). We draw on Allen's 
(2003) relational typology of power and power relations to tease out the diverse and overlapping modalities of power that operate to cohere a dispositif and produce governance capacity, beyond recourse to the 'command and control' capacities of the state. Indeed, as "a tangle, a multilinear ensemble" (Deluze 1992:159), governance capacity in a dispositif is not derived purely from disciplinary or regulatory varieties of command and control (Bissell 2018). Rather, the loosely connected elements and efforts composed and cohered in the dispositif are more likely to be orchestrated via modalities of power that Allen (2003) identifies as the "quieter" decentred forms of power exercised as diverse actants, located within and beyond the state, coordinate the actions of others.

Finally, and particularly important to our analysis, dispositif thinking takes us beyond assemblage analyses' emphasis on identifying and tracing elements and their connections, by focussing analytical attention on how diverse elements are cohered, however precariously, as a strategic response to produce the capacity to govern a particular problematic. It requires specific attention to how governing dispositifs emerge in contextualised, situated practice, always achieved through the gathering of heterogeneous elements in particular arrangements and through particular interventions, around particular and situated problems (Stripple and Bulkeley 2019). These elements are stitched together as a bricolage of techniques and practices that already exist and have no necessary common dimension other than the problem to which they are responding (Li 2007, Braun 2014). No common rationality that would unite the actants and practices gathered together is assumed, nor is territorial or political coherence across the various sources of authority that assert themselves in governing different urban domains. In the absence of reliance on a centralised steering logic from which governance is assumed to emerge, dispositif conceives of governance in piecemeal, contingent and precarious terms-as "a decentered totality that is ad hoc in its formation" (Braun 2014:52)-whereby sets of elements must be gathered and connections between them established to cohere governance capacity. This gathering of a loosely cohering assemblage is "a necessary and prior condition for any action to occur" (Braun 2008:671).

We are drawn therefore to recent work that explicitly deploys the analytical purchase of dispositif (eg Braun, 2014, Bissell 2018, Bracking 2019). Nonetheless, such applications of 
dispositif thinking still require more detailed specification of the processes and devices at work to compose and arrange diverse elements such that they are aligned to pursue collective goals and enable governance of specific 'problems'. We are concerned in this paper, therefore, to characterise processes and devices that gather together diffuse elements such that governance capacity is cohered across a heterogeneous dispositif, and the forms of power immanent in this composition and cohering. Consonant with the dispositif, we do not look for overarching plans but rather focus on multifarious interventions that 'pull together' diversely constituted elements (Li 2007). We ask three questions: What elements are being loosely assembled as a dispositif to generate a governance capacity to rework socio-material relations in desired ways? What processes and devices draw these assembled elements together? And what forms of power and authority are entailed in cohering the resulting dispositif? The paper thereby provides conceptual insights to refine understandings of the contemporary functioning of distributed urban governance, unpacks its complex, distributed and situated nature, and adds to an emergent body of work on how elements, processes and devices are composed, configured and cohered around urban energy governance (Stripple and Bulkeley 2019, M`Guirk et al 2016b).

\section{Mapping the energy governance dispositif in Sydney's top-tier commercial office space}

Energy governance in Australia is and remains fraught. Successive national governments have failed to produce a coherent stance on energy futures consistent with Australia's commitments to the Paris Agreement. The challenges of upgrading the energy system have fallen primarily to particular state government agencies and the urban (Dowling et al 2018). In this context, the emergent urban energy governance dispositif around top-tier commercial office space is embedded within multiple contending political projects that inform the city's wider governance aspirations around energy sustainability and the broad political economy of premium office space (M`Guirk et al 2019, Rutherford and Coutard 2014). Two dimensions are key. First is the City of Sydney's (CoS) long-established strategic ambition to achieve recognition as a global leader in sustainability (CoS 2014), including by focusing governance on the built environment such that "Sydney will be seen as a global 
leader for best practice in sustainability in buildings, precincts and urban development" (Better Buildings Partnership 2015:8). The office sector, which produces 45\% of the city's total emissions (CoS 2017), has been politicised as a central node in CoS's efforts towards global sustainability leadership. CoS has also taken a strongly pro-active stance in pursuing energy market reform, seeking to buoy Sydney's energy autonomy and demonstrate the city's leadership in this domain.

The second dimension embedding the dispositif is the context of Sydney's top-tier office market: $60 \%$ of the city's 5.09 million $\mathrm{m}^{2}$ of office space (Australia's largest concentration) is premium or A-grade and the majority of Sydney's high-performing office buildings are owned by top-tier commercial property portfolio investor firms (e.g. Investa, Dexus) (Bannister 2017). As environmental performance has become a key vector of value maintenance in built environment investment internationally, top-tier commercial office space is positioned as an 'exceptional urban space' wherein high commercial value facilitates higher aspirations around environmental performance (Tozer 2019) and an opportunistic node around which governance intervention might prove effective. Sydney's top-tier office space is identified globally as best practice for environmental performance with recent additions being showcased internationally (Carr et al 2018). Thus the concentration of Sydney's top-tier commercial buildings positions office space as a political agent in energy governance that might be conceived as an 'assemblage converter' (Haarstad and Wanvik, 2017), instrumental in reworking how energy governance is being realised and governance capacity produced. Effectively governing energy relies on the alignment between industry interests and territorial priorities (Huang and Castan-Broto 2018).

We turn now to 'mapping' the morphology of the emergent energy governance dispositif as it works on the ground. In doing so, we make no assumptions about the spatial or temporal configuration of governance or about the roles of the various actors regarding goal setting, steering and implementation. If a dispositif is 'a tangle; a multilinear ensemble', the task at hand is to 'draw up a map' via grounded observation (Deleuze, 1992:159). We achieve this through an inductive approach that involved interviews with over 30 key players in the commercial office and related policy sectors, including policy makers, property developers and those directly involved in building services and design and construction; a structured 
database of nearly 200 high-performing buildings drawn from information on alternative energy generation and energy efficiency measures; and analysis of documentation and grey literature around the sector. We do not seek to provide comprehensive or exhaustive identification of all elements, processes and devices in play (Haarstad 2016), nor consider them as prescriptive and generalisable across cities. Rather, our aim is to produce an account that aids more systematic understanding of the composition, cohering and operation of urban governance dispositifs.

The discussion that follows sketches the broad contours of the emergent energy governance dispositif in Sydney, outlining its key constitutive elements. Our 'map' of this dispositif has two components. First is a suite of key elements, political, legal, social and technical components whose capacities constitute nodal sites which, following Bracking (2019), when cohered have sufficient legitimacy to exercise some authority in building energy governance. The task is one of specifying how these elements are brought together to cohere in a functioning governing dispositif. The second component charts the processes and devices central to the work of composing and cohering through which governance capacity emerges. By processes we refer to the broad means through which elements are drawn together whereas devices operate as connective and ordering mechanisms. Crucially, these are not merely social: human actors, material practices and devices are bound up with each other in composing and cohering the dispositif. Indeed, various forms of technical, legal and financial devices are important mediators that corral diverse relationships into a coherent 'phenomenon' (Jensen et al 2016).

\subsection{Elements in context}

Just as Foucault insisted that a dispositif exists only when it is put into action (Foucault 1982, cited in Ploger 2008), so too work on urban energy governance has stressed its activation through context-specific encounters between urban processes, infrastructures and forms of management (Rutherford and Coutard 2014). We argue that six elements are central to these encounters and thus key to activating the emergent dispositif governing Sydney's top-tier commercial office space.

Strategies, plans and roadmaps. These include traditional, formal policy-oriented 
documents originating from local government, alongside roadmap documents originating from key private sector and not-for-profit institutions representing built environment and property industry interests nationally. Regardless of their state or non-state origin, these detail aspirational targets for the deployment of renewables; map the resources, supports and incentives available to help achieve desired targets; lay out steps, desired policy positions and regulatory schemes required locally and nationally to support aspirations; and set timelines against which targets must be met. Collectively, they articulate energy governance pathways in the context of wider aspirations towards sustainability and a zerocarbon built environment. They set the tone of debate and promote authoritative concepts (Haarstad 2016). Crucially, they do so in the context of parallel political projects within which these aspirations are considered feasible. The CoS Sustainable Sydney 2030 plan, for instance, embeds its targets within an agenda for global urban competitiveness and improved ranking in global city leagues. Similarly, the Green Building Council of Australia (GBCA 2018) positions its aspirations as part of competitive advantage for industry leaders, continuing to ensure Australia's competitiveness for investment as it reduces the carbonrelated risks that shape investment decisions and regulation.

Programs. These provide practical support and mechanisms to set achieving strategic aspiration in motion. Sydney's two dominant programs alternatively target building owners (Better Building Partnership (BBP)) and major commercial office tenants (City Switch). The programs are supported and administered by local government, though were devised and enacted collaboratively drawing on knowledge and expertise across the built environment sector. Each operates as an action network, drawing together voluntary program participants through which knowledge on improving environmental performance is circulated, focussed on reducing consumption and leveraging the value and reputational boosts to be gained from this.

Organisations/institutions. A host of organisations flank energy governance in the top-tier office space, from key government agencies to national peak advocacy bodies around sustainability and energy efficiency, to institutes and networks representing building and energy services. Some are state agencies at local and state government levels that administer the regulatory frame around building energy but also intermediate and advocate 
across other levels of government and the built environment sector. Others are non-state organisations with substantial capability (notably expertise) to orchestrate responses across their respective industries.

Mandatory regulation. Traditional, state-administered regulations set mandatory requirements for minimal performance standards and building environmental performance, administered at various scales: from a national building code, to NSW-specific requirements for minimum energy ratings for large-scale government-owned or -leased office buildings, to CoS planning regulations. Non-state institutions (eg GBCA) have had highly significant input into both the broad strokes and the fine detail of the regulatory framework.

Standards, benchmarks, rating and indices schemes. Mandatory and voluntary standards and ratings schemes are instrumental in boosting Sydney office buildings' energy performance (Bannister 2017). The National Building Energy Rating System (NABERS) is central, and mandates rating and disclosure (on sale or lease) for all office space above $1000 \mathrm{~m}^{2}$. The voluntary GBCA's Green Star rating is equally recognised as an important catalyst for new pathways in the sector and is used by governments "as proof that potential changes in policy are doable, tested and valuable" (GBCA 2018:36). These ratings are recognised as "capable of motivating all supply-side players and moving the market" (Bannister 2017). Additionally, international sustainability indices, such as the Dow Jones Sustainability index (DJSI) and Global Research Estate Sustainability Benchmark (GRESB), have become influential in guiding institutional property investment strategies (Affolderbach et al 2018), and are referenced in CoS's Sustainable Office Building Plan (2018:17). Indeed, between 2011 and 2018 the Australia real estate sector outperformed other regions, with more real estate companies and funds having set net zero emissions targets than any other region globally (GRESB 2018).

Green finance instruments. These either (i) create markets for energy-related projects and services that enhance the deployment of renewables and decentralised energy (eg Corporate Power Purchase Agreements, Environmental Performance Contracts, Green Leases) or (ii) channel financial resources towards energy-related projects in the office sector (eg Environmental Upgrade Agreements, Green Bonds). All major building service 
corporates operating in Sydney offer Environmental Performance Contracts and Power Purchase Agreements.

These elements reflect the multiscalar complexity of urban governance, encompassing local plans, national programs and legislative frameworks, and globally-circulating financial instruments. They suggest the nature of urban governance dispositifs as not simply urban but as a complex assemblage of institutions, networks and sociotechnical arrangements (Haarstaad 2016) operating across scales and through distinctive materialities.

\subsection{Processes and devices of composition and cohering}

We turn now to how the elements mapped above cohere to activate the urban governance dispositif that is effectively producing governance capacity around Sydney office buildings and energy. We identify four processes-intermediating, co-producing, financialising and legibilising-alongside a host of devices that together loosely connect diverse elements in a dispositif that generates order and enacts governance (Table 1). We see these processes and devices as the compositional forces that enable the 'particular arrangements' through which governance can be realised (Stripple and Bulkeley 2019).

\section{INSERT TABLE 1 HERE}

We make four observations as key to interpreting these processes and devices. First is recognition of their social and material character. Second is their emanation from and operation within and 'beyond-the-state' (Bulkeley and Schroder 2012): they operate at times collaboratively across the state and private sector, other times with limited or no state involvement, and they rely on a host of ordering devices that equally work across and between sectors ( $M \subseteq$ Guirk et al 2016a). Third, like their constituent elements, they are embedded in a diverse array of political projects and environmental, social and economic motivations. Fourth, and most substantively, these processes and devices entail heterogeneous forms of power that operate well beyond any remnant conception of the power of the state to govern by command. We excavate these four processes and their related devices before exploring the "quieter" decentred modes of power (Allen 2003) through which they work to cohere energy governance capacity. 


\section{(i) Intermediating}

Intermediating, as a process, brokers and supports connections between actors across sectors and domains of action. It expressly seeks to influence and coordinate the actions of others and transfer knowledge between them (Van Veelen 2019). In Sydney, intermediating is enacted by a range of actors - individuals, public bodies, NGOS or trade bodies - as well as by technical devices, including financial instruments, ratings schemes and data aggregating platforms. For example, the GBCA is the national advocacy body aimed to lead sustainable transformation of the built environment and its Carbon Positive Roadmap (2018) explicitly seeks to draw together policy makers, energy providers and building owners/tenants around a net-zero emissions building sector. Illustrating how intermediating is not exclusively social or institutional but also material, a host of devices within the Roadmap draw this constituency together behind a common agenda and connect this to policy makers, energy providers and regulators. Pathways, populated with key goals and actions, set out common ways to think about the problem of energy. Additional leveraging devices activate the pathways - pathway diagrams, industry-specific targets and timelines for their delivery, commitments to targets, best-practice guides. Consensus is forged also through the device of storylines that express the advantages of adhering to a pathway for both 'downstream' on-the-ground actors in the built environment and 'upstream' decision makers in the government and energy sectors.

Government agencies also intermediate across the dispositif to strategically align elements and capabilities towards desired ends. CoS's Sustainable Office Building Plan, for instance, sets out to connect actors cross-sectorally and cross-scale, and to enable them through financial resources, institutional contact networks, and creating further opportunities (Kivimaa and Martiskainen 2018:4):

"this plan will stimulate activity by advocating for higher minimum standards for new build and refurbishment work and mandatory disclosure of NABERS Energy ratings for tenancies... For the rest of the sector, we will continue our business support programs and to call for market signals and incentives to create market pressure. We will support accelerated uptake of renewable energy for all through advocacy, government partnerships and direct investment". 
Interests are also translated and actors are explicitly aligned, formalising and legislating their common interest via devices such as Green Leases, a recently established instrument designed through the CoS-led BBP (Janda et al 2016). These devices intermediate by shaping and consolidating relations of interdependence between owners and tenants (Van Veeling 2019). They provide templates that designate specific clauses about the responsibilities of building owners and tenants for buildings' environmental credentials and connect energy performance to another technological device: certification and rating schemes (Van Der Heijden 2017).

Crucially, though, intermediating is not an apolitical or neutral process: it is shaped within power relations and related logics that embed intermediaries as "political players in their own right" (Moss 2009:1485). The process is not simply a response to external influences, such as sustainability imperatives or technical changes in the energy sector, or to contextually specific conditions such as the materiality of building stock (Hodson et al 2016). Intermediating occurs in an already existing field in which intermediating actants are preexisting participants with embedded logics, priorities and interests (Parag and Janda 2014). Intermediating organisations manifest influence by aggregating opportunities for change (eg ASBEC 2016), mediating policy goals (eg GBCA) and enabling technology adoption (eg technically focused professional bodies). In Sydney, well-established building interests are turning attention to energy efficiency and reform, composing and cohering a governance dispositif that legitimates preferred governance arrangements that align with parallel political projects; whether by capitalising on the economic and reputational gains to be made from owning, leasing or investing in high-performing office spaces, or staking claims to 'global leadership' in sustainability. However, intermediaries' logics and priorities are not straightforwardly aligned in any predetermined way with particular sectors. Several of our interviewees reflected the porosity of sectoral boundaries, having moved fluidly between public and private institutions throughout their careers (Robin 2019), and drawing their expertise into the processes of bringing actants together across notional sectoral boundaries.

\section{(ii) Co-producing}


Co-producing emerges from the inevitable co-dependencies that inhere in the complex problem space of governing building energy, a space characterised by a multitude of partial, situated knowledges. Local government, for instance, depends on the expertise, local market knowledge and innovation opportunities associated with property owners, investors, managers, tenancies and financiers to devise appropriate support programs and effective regulations and policies. Likewise, the property and building industries require the cross-sectoral advocacy, informational and regulatory capacities of formal government actors to unpack barriers, develop markets and shape productive institutional practices and conditions. This co-dependency is declared in CoS's Sustainable Office Buildings Plan:

We cannot meet these (city targets for renewables and zero emissions) through the City's actions alone...The institutional owners... have the most capacity to innovate, test and de-risk new energy efficiency technologies, and to secure renewable energy supply to demonstrate pathways to net zero emissions (p.4/15).

Co-producing is an iterative means through which to cohere and steer such interdependencies by pooling the capacities of diversely positioned actants around problem definition and solving. The process draws together government capacities with the tacit knowledge of practitioners, and of governed subjects, to co-define and delimit problems, to collaboratively conceive of shared solutions and to collaborate on their delivery (Chatterton et al 2018). For example, the BBP was launched in 2011 to bring together the city's largest office property portfolio owners, $\operatorname{CoS}$ and university partners to collaborate on environmental performance, primarily in the top tier. It was initiated by CoS when the city "realised it was going to need some allies if they were going to go anywhere near achieving their...70\% greenhouse reduction by 2030 goal" (Sustainability Manager, large portfolio owner). The Partnership co-produced approaches, resources and devices to address barriers such that it now covers nearly $54 \%$ of the city's office space ( $>100$ buildings) and claims cuts to participants' emissions by 52\% on 2006 (Jewell 2018).

The diverse politics inherent in the composition and alignments enacted through coproducing reflects its basis in constituting mutual value and mutual benefit. BBP, for instance, explicitly reinforces CoS targets around emissions, renewables and wider 
sustainability which, in turn, are understood as markers of the city's aspiration for global green leadership:

The (BBP) has committed to achieve the City's vision and environmental targets. To achieve this and keep up with international best practice, owners and tenants must work together to maximise whole-building efficiency and secure renewable energy. (CoS 2018:22)

The politics of mutual benefit is also evident in media representation of co-produced initiatives. For instance, Fifth Estate (self-tagged as Australia's leading online newspaper for the sustainable built environment) reportage on BBP indicates the benefits for Council as well as for premium building owners in terms of leveraging reputational gain amongst the global sustainability benchmarks that influence institutional investment flows:

"This phenomenal result came about thanks to effective long-term collaboration between government and the private sector. Buildings account for more than 80 per cent of emissions generated in our area; we're fortunate to have some very collaborative and forward-thinking organisations to work with" .... GRESB head of Asia-Pacific Ruben Langbroek said the partnership was driving Australia's global reputation on building sustainability. (Jewell, 2018)

Like intermediating, co-producing emerges in an already existing field of interests and power relations.

\section{(iii) Financialising}

Financialising is key to composing and cohering the Sydney office energy governance dispositif. Two strands are discernable. One involves drawing together financial, environmental and building engineering interests and expertise to address the "financing gap" around energy retrofits via experimental financing devices (Knuth 2018).

Environmental Upgrade Agreements (EUAs), for example, are a form of building upgrade financing that draws together local government, commercial property owners and finance providers to provide tri-partite financing for commercial building retrofits. EUAs are devices of alignment that operationalise finance as a technology of governance. 
The second strand is the financialisation of environmental benchmarking indices that extract value by capitalising on the environmental performance of property portfolios. Indices such as GRESB operate in financialisation via calculatory devices that convert environmental performance into financial value by maintaining investment flows from risk-averse national and global investors:

big portfolio owners...have to demonstrate to their investors that they're actually behaving in a credible kind of way...so you've now got to be disclosing that you've considered the risk in relation to climate change issues associated with your portfolio... (Sustainability Manager, Building Services Consultancy)

The forms of calculation that underpin benchmarking indices commensurate disparate entities (Espeland and Stevens, 1998), and thus draw different actants together in a system of commodification that enables property's financialisation. Crucially, this draws in diversely positioned property interests by creating a new way of making sense of and acting on the 'problem' (Robin 2019) and shifting norms and practices in the industry in line with energy governance aspirations:

GRESB, they're all competing against each other...the portfolios, there's nowhere to hide. They've got to be in it to demonstrate that they're part of the game if you like...So for (office building portfolio owner) we're their advisor in relation to how they achieve their annual GRESB result. (Manager, Building Services Consultancy) In this context, strong performance in GRESB rating becomes a means of demonstrating environmental commitment and related reputational gains. GRESB draws actors to steps such as participating in the BBP or signing up to Green Leases to manage carbon-related risks to built-environment investments and to secure a strong rating.

Financialised indices have, therefore, become a key element and reference point in the dispositif, cohering programs, strategies, and diverse property interests around building energy governance. The GBCA's Roadmap, for instance, references GRESB's capacity to demonstrate an office sector environmental performance that will "ensure Australia's competitiveness and attractiveness for investment...[and] reduce carbon-related risks as they continue to come to the forefront of investment decisions and regulation" (2018:50). As an engineering consultancy observed: 
... portfolio investors are starting to ask the questions now ... around how efficient is your building? How robust is your building? How resilient is your building? Does it have an environmental rating? So that's also starting to drive behaviours....

(Sustainability Manager, Engineering Consultancy)

Moreover, the drive to secure competitive index ratings by managing environmental performance is linked to building owners/investors' aspirations to financially futureproof buildings around rental and investment yields, to some extent privileging the economic value of green standards over environmental performance (Cass 2018: 631). Thus many seek to monetise environmental performance as cost savings (controlling building operating costs) as "a calculable stream of value to capitalise into broader property exchange value and rents" (Knuth 2019: 497). This draws together cohorts of green entrepreneurs, energy services companies (ESCOs), financiers, global benchmarking indices, consulting firms etc. associated with the diverse products and devices of the energy-as-a service industries (Bracking 2019).

Financial instruments are part of a wider program of financialised energy governance that legitimates and enables particular kinds of governing action and facilitates a reliance on private investment (Webb 2019, Knuth 2018). Actors and devices are drawn together according to "how the market rewards those that choose to use low-carbon energy" (Sustainability Manager, large portfolio owner) or, as a consultant put it, "the fact that it's a building is an accident: it's an investment. ...(investors) frankly couldn't give a rat's that it's a building...sustainability...is good business" (Sustainability Manager, Engineering Consultancy). Thus, governance capacity composed and cohered via financialising is strongly shaped around market-oriented, calculative logics informed by financial incentives, futureproofing investment and enhancing market value and rental yields. These are clearly not exclusive of green logics. Indeed one strand of financialising is focused on releasing financial resources around energy retrofits. Yet economic logics and (largely private sector-derived) calculative systems emphatically underlie financialising as a process through which Sydney's office energy governance dispositif is emerging iii.

\section{(iv) Legibilising}


Legibilising shapes a way of understanding energy as a problem; making the problem 'readable' renders it amenable to particular forms of intervention and governance (Stripple and Bulkeley 2019). Legibility and visibility flow from each other; visibility being the mode of operation of legibility (Scott 1998). Legibilising involves various modes of visualising energy that craft commensurabilities, shape connections and thus gather varying sets of elements. We identify two interrelated strands.

One involves simply the visibility generated for 'the problem' through strategies, roadmaps and plans, which scope energy challenges and suggest specific ways of ordering the relevant domains to govern them, while providing a cohering discourse around governing energy to meet Paris Agreement commitments. As statements of intent, regardless of their source, these documents deploy narrative and graphical devices that shape new pictures of the building/energy nexus (Knuth 2019) and make visible the case for connecting regulatory and voluntary pathways, targets and policy frameworks that interpollate, draw together and responsibilise multiple actants. As one peak body put it, "We've identified the huge potential and impact that the building sector makes on emissions and, as such, in the energy market. We would like to see a more detailed roadmap for buildings ... which includes targets and metrics" (CEO). This is political work; how the problem is made legible and how this vision is circulated across multiple constituencies shapes conditions of possibility around governance capacity.

The second strand relates to rendering legible the abstract, immaterial form of energy. Devices such as audits, smart sub-metres, data analytics platforms and standards translate energy into data objects, making energy knowable and available to be acted upon. Visibility enables forms of calculation that, in turn, enable new relations to take shape around energy data, connecting it to evaluation and management techniques as it reveals sites and practices that warrant intervention (Kragh-Furbo and Walker 2018). As one portfolio owner said:

we have introduced a new suite of metrics which is much more comprehensive than we've been measuring before. We're in this data gathering stage of establishing the environmental performance attributes of each asset in a really consistent way so 
that we're able to do traffic lights...across every performance indicator...which is a big sell. (Sustainability Manager)

Thus energy-use visualised as data creates a 'physical proxy' capable of bringing desired objectives to light, demanding governance action ( $M \simeq$ Guirk et al 2019).

The composing and cohering agency of visibilising through data is acknowledged in CoS's (2018:31) Sustainable Office Buildings Plan: "Better data disclosure and sharing between parties is important to identify, incentivise and target tailored support to buildings, foster collaboration and accelerate the implementation of upgrades". Furthermore, it enables particular forms of economic value to be made as it renders energy transformation in calculable formats that capital can "see" (Robertson 2006), cohering connections between actants such as ESCOs, analytics platforms, metering technologies and global benchmarking organisations. Such visibility can induce accountability, discipline or incentivise performance and translate the benefits of environmental performance into reputational and related financial gain.

NABERS, for example, officially records and legibilises buildings' energy performance. While its mandatory nature endows authority, its wider composing and cohering agency lies in how it makes energy performance readable in a consistent and clear way, accepted by multiple actors as reliable (Bracking 2019). Its legitimacy has seen it become integrated across multiple state and non-state programs, strategies, organisations, and entailed in financialising, whereby its ratings are taken as a crucial data point. NABERS thus draws together and connects diverse entities and elements. The rating is woven through BBP and its sister program CitySwitch as participants commit to reaching given ratings; it is the standard by which the NSW Government Resource Efficiency Policy determines minimum performance for government-occupied office space; it features in the Property Council of Australia's Office Quality Guide; and it is part of the calculations used to determine the value proposition of Green Bonds. NABERS' readability endows it with portability (KraghFurbo and Walker 2018), and a capacity for drawing in and aligning heterogeneous actants in the dispositif:

When I started the Property Council, the GBCA, ASBEC, they were sitting out there and we were over here, and it was a very unpleasant world. Now...(w)e have that 
relationship with GBCA ...the president of the Property Council ... commented at our NABERS conference this year. They wouldn't have turned up three years ago... I've been invited to join the executive at ASBEC... As opposed to the old war that we used to have. (Senior Official, government department)

Legibilising is fundamental to how heterogenous interests and entities are drawn to and cohered in the energy governance dispositif. Yet, as the diverse nature of the devices involved makes clear, legibilising does not suggest "a synoptic vision emanating from a controlling center" (Lee 2014, 150) but a multi-step, uncertain and emergent process.

\subsection{Forms of power in composing and cohering the governance dispositif}

The four processes characterised above are central to the emergent building energy governance dispositif in Sydney. Foucault insists that any dispositif is inscribed in power and embedded in power relations. Thus we turn to asking what forms of power are entailed across the multiple lines of authority, capacities and interests that are effectively drawn to the dispositif and cohered to produce its capacity to govern? Responding to this question requires a relational view that understands power as a productive capacity produced in situated socio-material interactions is needed. Drawing on Allen's (2003) relational typology of power and power relations, we identify four modalities of power-decentralised well beyond state control-that overlap across the processes: inducement, persuasion, negotiation and authority (Table 1).

Inducement works across all four processes by mobilising the self-interests of parties and the benefits each accrues through adopting desired governmental aims. Intermediating strategy documents, such as CoS's Sustainable Office Building Plan and GBCA's Roadmap, are infused with storylines expressing these benefits. Co-produced programs explicitly articulate distinctive advantages for each partner and induce aligned sets of practices through co-producing resources (eg technical guides, tenant engagement guides).

Financialising induces alignments by commensurating environmental and financial gain for multiple actors, figured multifariously as costs savings, investment ratings, monetised reputational gain and the creation of new markets. Relatedly, Legibilising renders energy 
performance visible to those responsible for it and to their potential investors, inducing alignment with energy governance goals.

Persuasion is evident across Intermediating, Co-producing and Legibilising, each of which drives towards forging a mutual will across diverse interests (Bulkeley 2012). Intermediating crafts common ways of seeing via persuasive narratives and depictions of desired trajectories and through technical devices such as data aggregators that enable collective representations of building performance (eg Kinesis' CCAP product; Table 1). Co-produced pathways and best-practice guides persuade the governed towards profession-appropriate practices, articulating common barriers in common language and collaboratively designing pragmatic solutions. Legibilising persuades multiple constituencies to cohere around a common 'reading' of energy as a problem.

Negotiation is evident across Intermediating, Co-producing and Financialising, and it is exercised particularly through socio-technical devices through which terms of alignment are ordered. In Intermediating, Green Leases draw actors together around agreed-upon settlements that align practice. In Co-producing, co-dependent government and industry partners are connected through common arrangements developed through forums that work through their co-dependencies to produce technical fixes (such as guides, toolkits and Green Leases). Financialising depends on negotiating binding settlement terms that align actors via technical devices such as PPAs, EUAs and Green Bonds.

Finally, authority - recognition of the legitimacy of rule - is also exercised across all four processes: unsurprising, given its fundamental importance to the capacity to govern (Bulkeley 2012). Authority is exercised in Intermediating by drawing actants to constructed pathways and best-practice expectations that are accepted as authoritative because they have been devised by actors with trusted knowledge and competence (Rosenau 2002). In Co-producing, authority is established via the sectoral consensus developed around codesigned practices and programs and their concordance with formal government regulations (such as NABERS' integration in BBP). In Financialising, authority pivots around the legitimacy of the devices involved, and the calculatory logics and forms of commensuration that underpin them. This legitimacy translates across disparate networks 
to convince of investment value in the green economy (Webb 2019). Finally, authority operates in Legibilising via the legitimacy born of visibility; for example, notwithstanding its mandatory status, NABERS' authority to govern is arguably derived through its role in visibilising environmental performance which generates the consent and compliance of the governed (Kragh-Furbo and Walker 2018).

Our exploration demonstrates how the exercise of power in composing and cohering the office governance dispositif revolves around Allen's 'quieter' forms of power. These overlap across processes as diverse actants, within and beyond the state and embedded in diverse political priorities, steer the actions of others. 'Command and control' varieties of power that are more habitually associated with the exercise of state power and state-centred conceptions of governance (Dean 2010) are low key. Where state-auspiced forms of regulation are deployed (eg NABERS), they are empowered as much through their entailment in persuasion and inducement and their operation across varied cohering processes, as much as through their state-backed mandate. We argue that the inherent heterogeneity of the office energy governance dispositif - its heterogeneous geographies and topologies of power (Allen 2011) and the socio-material heterogeneity of the actants entailed in exercising power - requires this 'tangle' of modalities of power to effectively enable governance.

\section{Conclusion}

Urban scholarship has become more receptive to acknowledging the complexity and dynamism of urban governance, its connection to multiple lines of authority and forms of power, and its evolving socio-materiality as it seeks to respond to the challenge of producing governance capacity to address complex urban problems. Our analysis of Sydney's office energy governance dispositif reflects this dynamism and complexity. Our analytical lens allows us to parse the multiplicity of elements, materialities and motivations that constitute the dispositif and, crucially, the processes through which these are composed and cohered to activate the capacity to effectively govern a complex urban problem in which multiple logics are in play and state/non-state binaries are blurred. We reveal governance capacity as emergent rather than shaped by pre-determined forms of intervention: not exercised through sites of transcendent political control but through 
'quieter' forms of power. A key contribution of our analysis is the way we specify the processes and socio-material devices entrained in composing and cohering governing capacity across a multifaceted, distributed dispositif. This contribution refines systematic understandings and theorising of the contemporary functioning of distributed urban governance.

To conclude, we draw out two key observations for urban governance scholarship suggested by our analysis. First, the limits of analyses that conceive of governance in terms of synoptic visions enacted by pre-composed authoritative bodies will become ever more apparent as cities confront the increasingly complex governance problems engendered by, for example, anthropocene urbanism, smart urbanism (Derikson 2018) or indeed COVID-19. We argue that the analytical capacity of dispositif thinking can advance our ability beyond these limits to understand urban governance in terms of emergent, distributed and extra-state ecosystems wherein the question of how governance capacity is composed and cohered across a distributed dispositif becomes key. Governance capacity, as the case of Sydney's commercial office sector shows, is an inventive composition. It emerges as elements present themselves and are taken up as forms of government and drawn together by processes such as those analysed above, without being explicitly devised as such (Braun 2014, Kitchen et al 2017). This understanding highlights how, as Bouzarovski and Haarstad $(2018,264)$ observe, "conflicting objectives and ideologies may remain non-reconciled". Moreover it anticipates that there will be failures in composition, coherence and, therefore, in the capacity to govern. For instance, although Sydney's BBP is recognised as highly effective in governing energy to produce sustainability 'leadership' amongst top-tier office property interests, it has failed to cohere comparable capacity for the mid-tier office sector where 'leadership' does not resonate persuasively, is less recognised as a legitimate or authoritative driver, and is struggling to induce changed practices or create new channels of negotiation (Van Der Heijden, 2018). Critically, attending more closely to the malleability, plurality and failures of composing and cohering governance capacity across a distributed dispositif will enhance recognition of the potential of urban governance as a heterogenous space of political possibility, less easily tethered to dominant agendas, interests or aspirations than has previously been imagined. However, such attention equally raises critical questions around how multiple dispositifs might be aligned in attempts to produce 
the capacity to steer a city-itself an assemblage of assemblages-in response to particular problematics through which substantial challenges such as sustainability become known. A dispositif approach suggests that any such alignment would be emergent, inherently provisional, and embedded in both strategic intent and power relations.

Second, while conceiving of governance in terms of dispositif does not assume alignment between institutions, governing objectives, practices and technologies (Haarstad and Wanvik 2017), such alignment cannot be dismissed. Composing and cohering governance capacity is embedded in already configured fields of coexisting interests, motivations, political projects and social relations that shape the dispositif. The elements drawn in - the social and material 'comings-together' (Bracking 2019) - shape what is considered important to govern and how. Thus power, exercised in its multiple modalities, is immanent in the processes through which the dispositif is composed, such that it enables particular kinds of arrangements through which particular forms of government can emerge, embedded in existing fields of interest and often enabling their reproduction (Stripple and Bulkeley 2019, Scott 1998). In our analysis, for instance, the dominance of economic calculus and financial framings and the related need to demonstrate energy performance through data visualisations have strongly cohered the capacity of the energy governance dispositif around positioning top-tier office buildings in international investment markets and smart technology interventions, exercising power through inducement, persuasion, negotiation and authority. Yet this particular ordering excludes a range of other actors, institutions and materialities, notably those involved in mid-tier office space where different profiles of property ownership, building materialities and scales of investment produce a different suite of interests and aspirations. Key questions arising for broader urban governance scholarship include: What kinds of ordering do processes of composing and cohering governance capacity in particular urban domains produce and what might they exclude; and how do they align with (or disrupt) wider regulatory and political economic contexts (Kitchin et al 2017)? As our analysis of urban energy governance shows, dispositif thinking, buoyed by enhanced understanding of the processes and devices through which governance capacity is composed and cohered across distributed dispositifs, takes us forward in exploring such questions. 


\footnotetext{
' Müller 2015 notes how assemblage and the STS notion of actor-networks are taken as close equivalents with strong synergies between their language and conceptual bases, notwithstanding some key points of distinction (Anderson et al 2012).

ii These include commitments to the provisionality of the arrangements of heterogeneous elements in the formation; the ontological diversity of agency; the necessity of socio-material labours to hold together the formation; the consequent sense of the formation's capabilities as emergent; the play between stability and disruption; and a commitment that the formation need not cohere as a totality.

iii It may be tempting to read this aspect of financialising as a driving, unifying logic that mobilises intermediating, coproducing and legibilising towards the ends of aligning all things to allow for a complex and mediated system of market transactions. This logic is present to be sure; however, we align with dispositif thinking's insistence that no common unifying logic or rationality can be expected and indeed we illustrate other logics and motivations that are intertwined across the dispositif. Thanks to the anonymous reviewer for pushing us on this point.
}

\section{References}

Affolderbach, J., Preller, B., Schulz, C. 2018. Urban energy transitions through innovation in green building. In: König, A. (ed.) Sustainability Science: Key Issues. Routledge. New York \& Oxon, pp. 218-233.

Agamben, G., 2009. What is an Apparatus? Stanford University Press, Stanford, CA.

Allen, J., 2003. Lost geographies of power. Blackwell, Malden, MA.

Allen, J., 2011. Topological twists: power's shifting geographies. Dialogues in Human Geography, 1 (3), 283-298.

Allen, J., Cochrane, A. 2007. Beyond the territorial fix: Regional assemblages, politics and power. Regional Studies 41 (9), 1161-1175.

Anderson, B., Kearnes, M., McFarlane, C., and Swanton, D. 2012. On assemblages and geography. Dialogues in Human Geography 2: 171-189.

ASBEC. 2016. Low Carbon High Performance: How Buildings Can Make a Major Contribution to Australia's Emissions and Productivity Goals. Australian Sustainable Built Environment Council. https://climateworks.com.au/sites/default/files/documents/publications/summary_report__low_carbon_high_performance_20160511_1.pdf.

Bannister, P., 2017. Why is Australia better than the UK at building energy efficiency? Energy Management, January 18-20.

Better Buildings Partnership, 2015, Better Buildings Partnership. Annual Report 2013-2014. City of Sydney, Sydney.

Bissell, D., 2018. Automation interrupted: How autonomous vehicle accidents transform the material politics of automation. Political Geography, 65, 57-66.

Bouzarovski, S., Haarstad, H., 2018. Rescaling low-carbon transformations: Towards a relational ontology. Transactions of the Institute of British Geography 44, 256-269. doi: 10.1111/tran.12275

Bracking, S., 2019. Financialisation, climate finance and the calculative challenges of managing environmental change. Antipode, 51, (3), 709-729.

Braun, B., 2008. Environmental issues: inventive life. Progress in Human Geography, 32 (5), 667679.

Braun, B., 2014. A new urban dispositif? Governing life in an age of climate change. Environment and Planning D: Society and Space, 32, 49-64.

Bulkeley, H., 2012. Governance and the geography of authority: Modalities of authorisation and the transnational governing of climate change. Environment and Planning, 44(10), 2428-2444.

Bulkeley, H. 2015. Accomplishing Climate Governance. Cambridge University Press, Cambridge. 
Bulkeley, H., Betsill, M.M., 2013. Revisiting the urban politics of climate change. Environmental Politics, 22 (1), 136-154.

Bulkeley, H. and Schroder, H., 2012. Beyond state/non-state divides: Global cities and the governing of climate change. European Journal of International Relations, 7(1), 5-35.

Carr, C., M־Guirk, P.M., Dowling, R., 2018, Geographies of energy transition: the case of high performing commercial office space in the CBDs of Sydney and Melbourne, Australia. Australian Geographer, 50 (1) 29-48. doi: 10.1080/00049182.2018.1536319

Cass, N., 2018. Energy-related standards and UK speculative office development. Building Research \& Information, 46 (6), 615-635, doi: 10.1080/09613218.2017.1333351

Chatterton, P., Owen, A. , Cutter, J. , Dymski, G. and Unsworth, R., 2018, Recasting urban governance through Leeds City Lab: Developing alternatives to neoliberal urban austerity in coproduction laboratories. International Journal of Urban and Regional Research, 42, 226-243. doi:10.1111/1468-2427.12607.

City of Sydney, 2018. Sustainable Office Buildings Plan. City of Sydney, Sydney.

City of Sydney, 2017. Environmental Action: Strategy and Action Plan Draft. City of Sydney, Sydney. City of Sydney, 2014. Sustainable Sydney 2030: Community Strategic Plan. City of Sydney, Sydney.

Cupples, J. 2011, Shifting networks of power in Nicaragua: relational materialisms in the consumption of privatized electricity. Annals of the Association of American Geographers, 101 (4), 939-948, doi: 10.1080/00045608.2011.569654.

Dean, M., 2010. Power at the heart of the present: Exception, risk and sovereignty. European Journal of Cultural Studies, 13 (4), 459-475.

Deleuze, G., 1992. What is a Dispositif? In: Armstrong, T.J. (Ed.) Michel Foucault Philosopher. Harvester Wheatsheaf, New York, pp. 159-68

Derickson, K.D., 2018. Urban geography III: Anthropocene urbanism. Progress in Human Geography $42(3), 425-435$.

Dowling, R., M드uirk, P.M., Malleson, S., 2018. Governing energy transitions: exploring the role of the urban in multilevel governance. Energy Research and Social Science, 44, 260-67.

Espeland, W.N. and Stevens, M.L., 1998. Commensuration as a social process. Annual Review of Sociology 24, 313-343.

Evans, J. Karvonen, A., Raven, R., 2016. The experimental city: new modes and prospects of urban transformation. In: Evans J., Karvonen, A., Raven R., (Eds.) The Experimental City, Routledge, London, pp. 1-12.

Green Building Council of Australia, 2018. A Carbon Positive Roadmap for the Built Environment. GBCA, Sydney. https://gbca-web.s3.amazonaws.com/media/documents/carbon-positiveroadmap-discussion-paper-fa.pdf.

Haarstad, H., 2016. Where are energy transitions being governed? Conceptualizing the complex governance arrangements for low-carbon mobility in Europe. Cities 54, 4-10.

Haarstad, H., Wanvik, T. I., 2017. Carbonscapes and beyond: Conceptualizing the instability of oil landscapes. Progress in Human Geography, 41(4) 432-450.

Hajer, M., Nilson, M., Raworth, K., Baaker, P., et al (2015). Beyond cockpit-ism: Four insights to enhance the transformative potential of the sustainable development goals, Sustainability 7 , 1651-1660, doi:10.3390/su7021651.

Hodson, M, Burrai, E., Barlow, C., 2016. Remaking the material fabric of the city: 'Alternative' low carbon spaces of transformation or continuity? Environmental Innovation and Societal Transitions, 18, 128-146.

Huang, S., Castan-Broto, V., 2018. Interdependence between Urban Processes and Energy Transitions: The Dimensions of Urban Energy Transitions (DUET) Framework Environmental Innovation and Societal Transitions, 28, 35-45.

Janda, K., Bright, S., Patrick. J., Wilkinson, S., Dixon, T., 2016. The evolution of green leases: towards interorganizational environmental governance. Building Research and Information, http://dx.doi.org/10.1080/09613218.2016.1142811 
Jensen, J. S., Fratini, C. F., Cashmore, M. A., 2016. Socio-technical systems as place specific matters of concern: The role of urban governance in the transition of the wastewater system in Denmark. Journal of Environmental Policy and Planning, 18, 234-252.

Jewell, C., 2018. Better buildings partnership set to smash emissions targets, Fifth Estate, 26 March. https://www.thefifthestate.com.au/innovation/commercial/better-buildingspartnership-looks-set-to-smash-emissions-targets/.

Karvonen, A., Curgurullo, F., Caprotti, F., 2019. (Eds) Inside Smart Cities: Place, Politics and Urban Innovation, Routledge, London.

Kitchin, R., Colletta, C., McArdle, G., 2017. Urban informatics, governmentality and the logics of urban control, The Programmable City Working Paper no. 25. https://osf.io/preprints/socarxiv/27hz8/.

Kivimaa, P., Martiskainen, M., 2018. Dynamics of policy change and intermediation: the arduous transition towards low-energy homes in the United Kingdom. Energy Research and Social Science, 44, 83-99.

Knuth, S., 2018. "Breakthroughs" for a green economy? Financialization and clean energy transition. Energy Research \& Social Science 41,220-229.

Knuth, S., 2019. Cities and planetary repair: The problem with climate retrofitting. Environment and Planning A, 51, 487-504.

Kragh-Furbo, M, Walker, G., 2018. Electricity as (Big) Data: Metering, spatiotemporal granularity and value. Big Data \& Society, January-June, 1-12.

Legg, S., 2011. Assemblage/apparatus: using Deleuze and Foucault. Area, 43 (2), 18-133.

Lee, K., 2014. Feeling like a state: Design guidelines and the legibility of 'urban experience' in Singapore. International Journal of Urban and Regional Research, 38(1), 138-154.

Li, T.M., 2007. The will to improve: Governmentality, development, and the practice of politics. Durham: Duke University Press.

McCann, E., 2011. Veritable inventions: cities, policies and assemblage. Area, 43 (2), 143-47

McCann, E., and Ward, K. 2011. Mobile Urbanism: City Policymaking in the Global Age. Minneapolis: University of Minnesota Press.

McFarlane, C. 2009. Translocal assemblages: space, power and social movements. Geoforum, 40, 561-567.

Ḿuirk, P. M., Bulkeley, H., Dowling, R., 2016b. Configuring urban carbon governance: Insights from Sydney, Australia. AAAG, 106, 145-166.

MGuirk, P. M., Mee, K., Ruming, K., 2016a. Assembling urban regeneration? Resourcing critical generative accounts of urban regeneration through assemblage thinking. Geography Compass, 10 (3), 128-141.

MGuirk, P. M., Dowling, R., Carr, C., 2019. The material politics of smart building energy management: a view from Sydney's commercial office space. Political Geography $\underline{74}, 102-$ 34doi.org/10.1016/j.polgeo.2019.102034

Moss, T., 2009. Intermediaries and the governance of sociotechnical networks in transition. Environment and Planning A, 41(6), 1480-95.

Müller, M. 2015. A half-hearted romance? A diagnosis and agenda for the relationship between economic geography and actor-network theory (ANT). Progress in Human Geography 39: 65-86.

Parag, Y., Janda, K., 2014. More than filler: Middle actors and socio-technical change in the energy system from the "middle-out". Energy Research \& Social Science, 3, 102-112.

Ploger, J., 2008. Foucault's dispositif and the city. Planning Theory, 7(1), 51-70.

Prince, R., 2014. Consultants and the global assemblage of culture and creativity. Transactions of the Institute of British Geographers. 39(1), 90-101.

Rabinow, P. and Rose, N., 2003. Foucault today. In Rabinow, P. and Rose, N. eds The Essential Foucault: Selections from the Essential Works of Foucault, 1954-1984. New Press, New York vii-xxxv. 
Robertson, M., 2006. The nature that capital can see: Science, state, and market in the commodification of ecosystem services. Environment and Planning D, 24 (3), 367-387.

Robin, E., 2019. Performing real estate value(s): real estate developers, systems of expertise and the production of space. Geoforum https://doi.org/10.1016/j.geoforum.2018.05.006

Rosenau, J. N., 2002. NGOs and fragmented authority in globalizing space. In: Ferguson, Y.H., Barry Jones, R.J (Eds.) Political Space: Frontiers of Change and Governance in a Globalizing World, State University of New York Press, Albany, pp 261-280.

Rutherford, J., 2014. The vicissitudes of energy and climate policy in Stockholm: politics, materiality and transition. Urban Studies, 51 (7), 1449-1470.Rutherford, J., Coutard, O., 2014. Urban energy transitions: places, processes and politics of socio-technical change. Urban Studies, 51, 1353-1377.

Rydin, Y. 2013. Using Actor-Network Theory to understand planning practice: Exploring relationships between actants in regulating low-carbon commercial development. Planning Theory, 12, 23-45.

Scott, J. C., 1998. Seeing like a state: How certain schemes to improve the human condition have failed. Yale University Press, New Haven and London.

Stone, C., 1989. Regime Politics: Governing Atlanta 1946-1988. University Press of Kansas, Lawrence.

Stripple, J. Bulkeley, H., 2019. Towards a material politics of socio-technical transitions : Navigating decarbonisation pathways in Malmö. Political Geography, 72, 52-63.

Tozer, L., 2019. The urban material politics of decarbonization in Stockholm, London and San Francisco. Geoforum, 201, 106-115.

Van Der Heijden, J., 2018. From leaders to majority: a frontrunner paradox in built-environment climate governance experimentation. Journal of Environmental Planning and Management, 61 (8), 1383-1401, doi: 10.1080/09640568.2017.1350147.

Van Der Heijden, J., 2017. Eco-financing for low-carbon buildings and cities: Value and limits. Urban Studies, 54 (12), 2894-2909.

Van Veelen, B., 2019. Caught in the middle? Creating and contesting intermediary spaces in lowcarbon transitions, Environment and Planning C, doi: 10.1177/2399654419856020.

Webb, J., 2019. New lamps for old: financialised governance of cities and clean energy. Journal of Cultural Economy, doi: 10.1080/17530350.2019.1613253.

\section{Table 1}

Cohering processes, enabling devices and forms of power: indicative examples.

\section{TABLE 1}

\begin{tabular}{|c|c|c|}
\hline PROCESSES & INDICATIVE EXAMPLES of ELEMENTS COHERED & INDICATIVE D \\
\hline Intermediating & $\begin{array}{l}\text { - Green Building Council of Australia Carbon Positive Roadmap } \\
\text { - Australian Built Environment Council (ASBEC) Low Carbon High Performance } \\
\text { Report } \\
\text { - City of Sydney Sustainable Office Buildings Plan } \\
\text { - NABERS } \\
\text { - CCAP precinct-level data aggregating platform (Kinesis software-as-a-service } \\
\text { product) }\end{array}$ & $\begin{array}{l}\text { - Pathways } \\
\text { - Storylines / } \\
\text { - Targets and } \\
\text { - Technical gu } \\
\text { - Green Lease } \\
\text { - Standards }\end{array}$ \\
\hline Co-producing & $\begin{array}{l}\text { - Better Buildings Program } \\
\text { - Chartered Institute of Building Services Engineers' PRIME strategy }\end{array}$ & $\begin{array}{l}\text { - Technical w } \\
\text { - Best practic } \\
\text { - Toolkits } \\
\text { - Devices of r } \\
\text { - Pathways }\end{array}$ \\
\hline
\end{tabular}




\begin{tabular}{|c|c|c|}
\hline Financialising & $\begin{array}{l}\text { - Green bonds } \\
\text { - NABERS } \\
\text { - GRESB }\end{array}$ & $\begin{array}{l}\text { - Standards/R } \\
\text { - Data flows } \\
\text { - Data analyti }\end{array}$ \\
\hline Legibilising & $\begin{array}{l}\text { - NABERS } \\
\text { - Green Star } \\
\text { - CitySwitch } \\
\text { - City of Sydney Sustainable Office Buildings Plan } \\
\text { - Green Building Council of Australia, Carbon Positive Roadmap } \\
\text { - Australian Built Environment Council (ASBEC) Low Carbon High Performance } \\
\text { Report }\end{array}$ & $\begin{array}{l}\text { - Pathways } \\
\text { - Storylines/N } \\
\text { - Pledges/com } \\
\text { - Devices of re } \\
\text { - Data flows } \\
\text { - Data analytic } \\
\text { - Standards/R }\end{array}$ \\
\hline
\end{tabular}

